\title{
Effects of magnesium pemoline on food and water intake in rats'
}

\author{
WILLIAM J. PIZZI ${ }^{2}$, CHARLES S. SEE, III, ILLINOIS \\ INSTITUTE OF TECHNOLOGY, Chicago, Illinois, AND \\ HERBERT M. KOHN, ILLINOIS STATE PSYCHIATRIC \\ INSTITUTE, AND ILLINOIS INSTITUTE OF TECHNOLOGY, \\ Chicago, Illinois
}

$A$ decrease in food intake appears following single injections of placebo or magnesium pemoline. Continued placebo injections do not produce this decrease while continued magnesium pemoline injections do maintain this decreased food consumption. Water consumption is not altered by these injections.

Recent studies of the effects of magnesium pemoline, a mild CNS stimulant, have led to two different interpretations of the behavioral effects. One interpretation posits enhanced learning or memory (Plotnikoff, 1966; Plotnikoff, 1966; and Plotnikoff \& Meekma, 1967), while the second views the evidence as supporting a performance variable (Beach \& Kimble, 1967; Frey \& Polidora, 1967; Powell, Martin, \& Kamano, 1967).

The purpose of this study is to investigate the effects of magnesium pemoline on food and water intake in order to determine whether motivational variables are acting.

Food and water intake were measured for three days prior to administration of the drug. The amount of food and water consumed was determined by placing known quantities of each in the animal's cage and measuring the remains at $24 \mathrm{~h}$ intervals. Error in water data due to leakage or evaporation was less than $1 \%$. Food which fell through the cage floor was collected, weighed, and amount consumed appropriately adjusted. Following the preinjection measures, the animals were matched on food intake and divided into groups for testing.

The drug groups were injected with magnesium pemoline (approx. $20 \mathrm{mg} / \mathrm{kg}$, I. P., in an $0.3 \%$ tragacanth suspension) while the placebo groups received equivalent volumes of the tragacanth suspension. Food and water consumption were determined once, $24 \mathrm{~h}$ following each injection. In order to control for possible injection effects, those animals that originally received the placebo were given the drug in a second injection. Similarly, those animals originally given the drug received the placebo on this second injection. Injections were separated by four days. The Ss were 32 male albino rats of the Sprague Dawley strain weighing 250-350 g.

Table 1 shows the group means for food and water consumption and significance levels. Three results are evident from this analysis. First, drugged animals eat significantly less than placebo animals, when compared within a given injection. Second, there is an injection effect shown by the significant decrease in food intake from preinjection levels following the first injection, regardless of the content of the injection. This initial injection effect adapts out on the second injection. Animals drugged on either first or second injections differ significantly from second injection placebo animals indicating that there is no adaptation to the drug over the two administrations. Postinjection water consumption was not different from preinjection levels and following injection the groups did not differ in water consumption. This can be interpreted as evidence of a specific effect of the drug on food consumption.

Figure 1 shows the results of a second experiment carried out to replicate the original and to expand the number of injections to four. This time 14 rats were used. The results are plotted as a decrease in food intake as a function of injection. It is clear that the drug effect on food intake does not diminish but that the injection placebo animals indicating that there is no adaptation to the drug over the two administrations. Postinjection water injection, preliminary data indicate water consumption rises significantly which may be a result of food and water interaction or a delayed drug effect.

Adaptation of food consumption to the effect of an injection occurs only after a number of injections and it thus seems that a
Table 1.

Means, Standard Deviations and Significance Levels (determined by a two-tailed $t$ test for mean difference) for $24-h$ food and water consumption of drugged $(\mathrm{N}=16)$ rats (NS above .05 probability)

\begin{tabular}{|c|c|c|c|c|c|c|c|c|}
\hline & \multicolumn{4}{|c|}{ PREINJECTION } & \multicolumn{4}{|c|}{ POSTINJECTION } \\
\hline & \multicolumn{2}{|c|}{ Food } & \multicolumn{2}{|c|}{ Water } & \multicolumn{2}{|c|}{ Food } & \multicolumn{2}{|c|}{ Water } \\
\hline & $\mathrm{X}$ & SD & $\mathrm{X}$ & $\mathrm{SD}$ & $\mathbf{X}$ & SD & $\mathrm{X}$ & $\mathrm{SD}$ \\
\hline Drug & 26.7 & 3.3 & 41.4 & 13.5 & 13.1 & 4.2 & 34.1 & 8.3 \\
\hline Placebo 1 & 26.4 & 3.4 & 35.6 & 4.5 & 17.4 & 4.5 & 35.5 & 15.4 \\
\hline Drug 2 & 26.4 & 3.4 & 35.6 & 4.5 & 19.3 & 3.5 & 41.3 & 6.8 \\
\hline Placebo 2 & 26.7 & 3.3 & 41.4 & 13.5 & 26.1 & 3.8 & 45.1 & 16.4 \\
\hline
\end{tabular}

\begin{tabular}{lccccccc} 
& \multicolumn{3}{c}{ Food } & P“t” & & \multicolumn{3}{c}{ Water } \\
\cline { 2 - 4 } \cline { 6 - 7 } \cline { 5 - 7 } & Drug 2 & Placebo 1 & Placebo 2 & & Drug 2 & Placebo 1 & Placebo 2 \\
\hline Drug 1 & .001 & .02 & .001 & & NS & NS & NS \\
Drug 2 & & NS & .001 & & NS & NS \\
Placebo 1 & & & .001 & & & NS \\
\hline
\end{tabular}

series of preexperimental injections should be instituted to eliminate confounding effects of injection trauma. A task utilizing food reward to investigate the effects of pemoline on learning and memory is contraindicated. Similarly, since food intake affects water intake, any task utilizing water reinforcement is also contraindicated unless there is an interval of several days between injection and testing. The hunger and thirst paradigms have been adopted in evaluating amphetamine and the resultant interaction makes interpretation of the data equivocal (Cole, 1963).

Our findings suggest that pemoline has an action similar to amphetamine in that it decreases food intake. Other investigators have demonstrated an increase in activity, following injections of both pemoline (Beach \& Kimble, 1967) and amphetamine (Cole, 1963; Yagi, 1963). These studies and recent work (Morris, Aghajanian, \& Bloom, 1967; Stein \& Yellin, 1967) contradicting an earlier report (Glasky \& Simon, 1966) that pemoline increases brain RNA polymerases indicate that further investigations into the physiological and behavioral effects of pemoline need to be evaluated before attempting to interpret this drug as a memory enhancing agent.

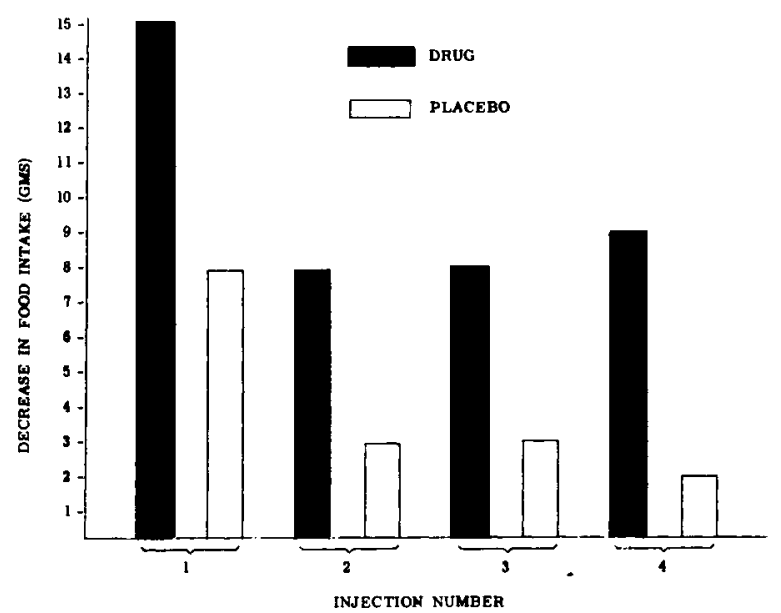

Fig. 1. Decrease in food intake in grams (ordinate) for a series of four injections (abscissa). Food intake decreases after the second placebo injection and is close to preinjection levels, but normal intake is not approached even after four drug injections. 


\section{REFERENCES}

BEACH, G., \& KIMBLE, D. P., Activity and responsivity in rats after magnesium pemoline injections, Science, 1967, 155, 698-701.

COLE, S. O., Interaction of amphetamine with conditions of food deprivation, Psychol. Rep., 1963, 13, 387-390.

FREY, P. W., \& POLIDORA, V. J., Magnesium pemoline: Effect on avoidance conditioning in rats, Science, 1967, 155, 1281-1282.

GLASKY, A. J., \& SIMON, L. N., Magnesium pemoline: Enhancement of brain RNA polymerases, Science, 1966, 151, 702-703.

MORRIS, N. R., AGHAJANIAN, G. K., \& BLOOM, F. E., Magnesium pemoline: Failure to affect in vivo synthesis of brain RNA, Science, 1967, $155,1125-1126$.

PLOTNIKOFF, N., Magnesium pemoline: Enhancement of learning and memory of a conditioned avoidance response, Science, 1966a, 151, 703-704.

PLOTNIKOFF, N., Magnesium pemoline: Enhancement of memory after electroconvulsive shock in rats, Life Sciences, 1966b, 5, 1495-1498.

PLOTNIKOFF, N., \& MEEKMA, P., Pemoline and magnesium hydroxide versus pemoline: Enhancement of learning and memory of a conditioned avoidance response in rats, J. Pharmacol. Sciences, 1967, 56, $290-291$.

POWELL, B. J., MARTIN, L. K., \& KAMANO, D. K., Magnesium pemoline: Effects of training vs. testing of an avoidance response, Psychon. Sci. 1967, 8, 205-206.

STEIN, H. H., \& YELLIN, T. O., Pemoline and magnesium hydroxide: Lack of effect on RNA and protein synthesis, Science, 1967, 157, 96-97.

YAGI, B., Studies in general activity: III The effects of methamphetamine, Annu. anim Psychol., Tokyo 1963, 13, 37-47.

\section{NOTE}

1. We thank Frank Muno, RPH, for the preparation of all drugs, and Dr. H. G. Schoepke, Abbott Laboratories, for providing the magnesium pemoline. This research was supported by the Department of Psychology, Illinois Institute of Technology, and the Mental Health Fund, Department of Mental Health, State of Illinois.

2. Present address: Institute for Psychosomatic and Psychiatric Research and Training; Michael Reese Hospital, Chicago, Illinois 60616. 